\title{
Analysis of Patient Characteristics, Financing of Actions and Diagnosis of Disease in BPJS Patients
}

\author{
Evy Syagran $^{1,2}$, Budhi Setianto ${ }^{3,4}$, \\ Agus Aan Adriansyah ${ }^{4}$, Eppy \\ Setiyowati $^{5}$, Nikmatus Sa'adah ${ }^{6}$ \\ ${ }^{1}$ Dentist of Rumah Sakit Islam \\ Surabaya 60243, East Java, \\ ${ }^{2}$ Department of Early childhood \\ education programs, Faculty of \\ Medicine, Universitas Nahdlatul \\ Ulama Surabaya 60237, East Java, \\ Indonesia \\ ${ }^{3}$ Head of Marketing Rumah Sakit \\ Islam Surabaya 60243, East Java, \\ Indonesia \\ ${ }^{4}$ Department of public health, \\ Universitas Nahdlatul Ulama \\ Surabaya, 60237, East Java, Indonesia \\ ${ }^{5}$ Department of Nursing, Faculty of \\ Nursing and midwifery, Universitas \\ Nahdlatul Ulama Surabaya \\ ${ }^{6}$ Dentistry Study Program, Faculty of \\ Dentistry Bhakti Wiyata Institute of \\ Health Sciences, Kediri
}

Email

budhisetianto@yahoo.com

Received : October $4^{\text {nd }} 2021$

Accepted : October $15^{\text {rd }} 2021$

Published : November $27^{\text {th }} 2021$

\begin{abstract}
Background: Dental and oral health services are a form of professional service that is an integral part of health services for the community, families or individuals3. Implementation of a dental specialist clinic at the 2nd health facility is a referral from the health facility 1 All financing is borne by BPJS with INA CBGS financing. Purpose: This study aims to determine patient characteristics and disease diagnosis of BPJS patients in specialist dental clinic in Islamic Hospital Surabaya. Methods: This study used a qualitative research method with a descriptive analytic study. From the BPJS TXT data for January - December 2019, there were 7153 patient visits at the dental specialist clinic of the Islamic Hospital in Surabaya, the TXT data is data issued by the BPJS as a result of purification of billing file data recognized by the BPJS. Results: Based on the results of the study, it was found that most of the patients were male, with the largest age ranges being $<25$ years and $>50$ years. The implementation of the tariff difference between INA CBGS and the fare difference of the Islamic Hospital in Surabaya is - 128,091,924 with an average of 17,907 / patient. Of the total TXT, the largest financing of the INA CBGS tariff is the doctor service rate with a percentage of 54.90\%. Conclusion: the implementation of BPJS examination of specialist dental polyclinic at RS Islam Surabaya did not give the maximum benefit.
\end{abstract}

Keywords: BPJS, Characteristic, Dental Clinic, Diagnosis, Hospital

This is an open-acces article distributed under the terms of the Creative Commons AttributionShareAlike 4.0 International License.

\section{INTRODUCTION}

Health care is the right of each person as ensured in the Constitution of the Republic of Indonesia year 1945 which must be carried out in an effort to increase the health of citizens(Kementerian Kesehatan Republik Indonesia, 2009). Hospitals as providers of referral health services, must provide quality and fair health services for the community(Suharmiati et al., 2019).

Hospital is a health care institution is a reference of the first level of health facilities that have several complete facilities must always be able to improve more quality services and affordable by citizens in order to realize health degree as high(Kementerian Kesehatan Republik Indonesia, 2009). 
Dental and oral health services are a form of professional services that are an integral part of health services for the community, family or per person(Andayasari, 2014). Some of the examinations that will be carried out at the basic dental poly are: conducting treatment and examination to oral and dental diseases, services in dental poly performed by doctors who are assisted by dental nurses some actions performed in dental poly are (1) Patching, (2) Extraction, (3) Cleaning of tartar, (4) Treatment of root canal (pulp capping), (4) Counseling, (5) Referral(Dewanto, 2014).

In carrying out its duties Health Insurance Organizing Agency (BPJS) Health continues to increase spread in all corners of the country. Not only that, some types of services covered by BPJS Health is also quite extensive, ranging from illness and minor to severe diseases. And no less interesting than BPJS health facilities is a dental health service(Ridha Aulia, Rosihan Adhani, Irham Taufiqurrahman, 2017). All facilities obtained by patients for level I health facilities are free of charge, the financing received by level I health facilities is by the capitation system. Capitation Rate is the amount of monthly payments paid upfront by BPJS Kesehatan to Early Level Health Facilities sourced to the number of registered Participants regardless of the type and number of health services provided(Dewanto, 2014).

If in a situation where health service one level can't perform the procedure on dental poly, then a referral is required to be done by a dentist located in the nearest hospital(Ridha Aulia, Rosihan Adhani, Irham Taufiqurrahman, 2017). Specialist dentists are dentists who specialize in a particular field of dentistry here are some doctors who can work in health service two level(Menkes RI, 2005). The ability possessed by a person specialist orthodontist is to diagnose developmental abnormalities and growth of teeth and face (dentofacial), and methods of countermeasures through preventive, interceptive and curative efforts both surgically and non-surgically, in order to restore the maximum system of chewing and aesthetics(Lisnawaty, 2008).

Periodontia Specialist (Sp.Perio). Sp.Perio capabilities include dental support tissue treatment, a kind of bloody gum treatment, inflamed gums, shrinkage of the gums, teeth shakes, obliterating tartar, periodontal surgery, and so on(Meisida et al., 2014). The regulation of the ministry of health, has actually given direction that the field of dentistry is already positioned in the first primary / strata service in the national health system.(Konsil Kedokteran Indonesia, 2012) Financing applied to primary care dentists in the JKN system using the capitation system, If the dentist's services are included in the secondary or second strata services then the calculation for dental care is certainly calculated based on each treatment performed (using $C B G^{\prime} s I N A$ ) which will definitely require a higher cost of. Ina CBGS tariff is a package fare that includes all components of hospital resources used in both medical and nonmedical services(Anas \& Abdullah, 2008).

The financing rate of each patient in the services provided should not exceed the INA CBGS rate guaranteed by BPJS. Efficiency measures in quality control and cost control are very important to implement, so as not to suffer losses. The importance of unit cost calculation in each service provided to patients so that it does not suffer (Duarsa et al., 2019) Unit cost is the cost required in per unit of product or cost per service. fare is part or all of the payment of service activities in the hospital, which is charged to the citizens in return for the services received. Tariff pattern is a basic guideline in the regulation and calculation of tariff amount. Hospital rates are calculated on the basis of unit cost of each type of service. The purpose of this study is to write TXT data in verification of claims BPJS poly teeth Patient Characteristics, Financing Actions (unit Cost) and Disease Diagnosis in BPJS Patients.

\section{MATERIALS AND METHODS}

This research uses qualitative research methods with descriptive analytical studies. From BPJS TXT data in January - December 2019 as many as 7153 patient visits at poly dental specialist RS Islam Surabaya, TXT data is data issued by BPJS as a result of purification of billing file data recognized by BPJS. 


\section{RESULTS}

a. Patient Demographics

Table 1 Characteristics by Patient Gender

\begin{tabular}{llcc}
\hline No. & Gender & $\mathrm{N}$ & $\%$ \\
\hline 1 & woman & 1.493 & $20,9 \%$ \\
2 & Male & 5.660 & $79,1 \%$ \\
\hline & Grand Total & 7.153 & $100,0 \%$ \\
\hline
\end{tabular}

On the table 1 , the majority of patients were male by $79.1 \%$

Table 2 Characteristics by age patient

\begin{tabular}{llcc}
\hline No. & Range age & $\mathrm{N}$ & $\%$ \\
\hline 1 & $<25$ year & 2043 & $28,6 \%$ \\
2 & $25-30$ year & 783 & $10,9 \%$ \\
3 & 31 - 35 year & 518 & $7,2 \%$ \\
4 & $35-40$ year & 617 & $8,6 \%$ \\
5 & $41-45$ year & 600 & $8,4 \%$ \\
6 & $46-50$ year & 755 & $10,6 \%$ \\
7 & $>50$ year & 1837 & $25,7 \%$ \\
\hline & Grand Total & 7153 & $100,0 \%$ \\
\hline
\end{tabular}

In Table 2 patients were $<$ of 25 years old at $28.6 \%$ and $>50$ years old at $25.7 \%$

b. Difference between Ina CBGS fare and Hospital fare

Hospital rates are the amount of revenue received by the Hospital for actions / services from services and non-services provided to service users(Duarsa et al., 2019). Tariff is the amount of Unit cost + constant. While the INA CBGS fare is the size of the package fare unit which is the entire component of hospital resources used in both medial and non-medical services. To be able to provide the benefits of a service tariff INA CBGS must be higher than the service rate, so that actions in the service can contribute to the benefits. Conversely, if the hospital tariff is higher than the INA CBGS tariff, it will provide no contribution of profit or loss.

Table 3 Difference between INA CBGS fare and Hospital fare

\begin{tabular}{llrrrr}
\hline No. & Dental Specialists & $\mathrm{N}$ & fare INA CBGS & Hospital Rates & Fare Difference \\
\hline 1 & Oral Surgery & 3.094 & 741.508 .500 & 758.626 .138 & -17.117 .638 \\
2 & Children's Dental & 1.485 & 394.649 .100 & 435.293 .017 & -40.643 .917 \\
& Health & & & & \\
3 & Perio & 627 & 180.379 .600 & 201.751 .039 & -21.371 .439 \\
4 & Anak Dental & 1.947 & 552.276 .300 & 601.234 .600 & -48.958 .300 \\
& Conservation & & & & \\
\hline & Grand Total & 7.153 & 1.868 .813 .500 & 1.996 .904 .794 & -128.091 .294 \\
\hline
\end{tabular}


Based on Table 3, it is obtained that from every action provided by specialist dental services suffered losses with a total loss of 128,091,294 during 2019. Here is the difference between the average INA CBGS compared to the hospital rate in specialist dental poly services per dental specialist.

Table 4 Difference between Average Ina CBGS Tariff compared to Hospital Rates in Services based on dental Specialist

\begin{tabular}{llrrr}
\hline No. & Dental Specialists & $\begin{array}{r}\text { Fare INA GBS } \\
\text { average }\end{array}$ & $\begin{array}{r}\text { Average } \\
\text { Rate/Patient }\end{array}$ & $\begin{array}{r}\text { Difference } \\
\text { between Ina CBGS } \\
\text { and patient }\end{array}$ \\
\hline 1 & Oral Surgery & 239.660 & 245.193 & -5.533 \\
2 & Children's Dental Health & 265.757 & 293.127 & -27.370 \\
3 & Perio & 287.687 & 321.772 & -34.085 \\
4 & Dental Conservation & 283.655 & 308.801 & -25.146 \\
\hline & Average & 261.263 & 279.170 & -17.907 \\
\hline
\end{tabular}

Based on Table 4, it is obtained that the average rate of INA CBGS compared to hospital rates in service per dental specialist is $(17,907)$ per patient. The following is the Average Rate of Ina CBGS compared to Hospital Rates in Dental Action Type Services are as follows:

Table 5 Difference in Average Ina CBGS Rates compared to Hospital Rates in Services by type of action

\begin{tabular}{|c|c|c|c|c|c|c|}
\hline No. & Action Type & $\mathrm{N}$ & $\begin{array}{l}\text { Total Tariff Ina } \\
\text { CBGS }\end{array}$ & $\begin{array}{l}\text { Total hospital } \\
\text { Rate }\end{array}$ & $\begin{array}{l}\text { Total Cost } \\
\text { difference }\end{array}$ & $\begin{array}{c}\text { Cost } \\
\text { Difference } \\
\text { Per Patient } \\
\end{array}$ \\
\hline 1 & Fracture & 7 & 1.029 .700 & 1.495 .000 & (465.300) & $(66.471)$ \\
\hline 2 & Teeth and Problems & 693 & 151.974 .900 & 142.823 .457 & 9.151 .443 & 13.206 \\
\hline 3 & Other acute diseases & 24 & 4.651 .200 & 4.181 .811 & 469.389 & 19.558 \\
\hline 4 & $\begin{array}{l}\text { Other Minor } \\
\text { Chronic Diseases }\end{array}$ & 2.073 & 398.845 .200 & 394.690 .717 & 4.154 .483 & 2.004 \\
\hline 5 & $\begin{array}{l}\text { Prosedur Aplikasi } \\
\text { Casts dan splints }\end{array}$ & 1 & 292.300 & 435.000 & $(142.700)$ & $(142.700)$ \\
\hline 6 & $\begin{array}{l}\text { Large Oral and } \\
\text { Tongue Procedures }\end{array}$ & 2 & 674.200 & 666.486 & 7.714 & 3.857 \\
\hline 7 & $\begin{array}{l}\text { Small Procedure on } \\
\text { Ears, Nose, Mouth } \\
\text { and Throat }\end{array}$ & 322 & 103.909 .400 & 97.133 .406 & 6.775 .994 & 21.043 \\
\hline 8 & $\begin{array}{l}\text { Small Procedure on } \\
\text { Mouth and Tongue }\end{array}$ & 24 & 6.480 .000 & 8.088 .180 & $(1.608 .180)$ & ( 67.008) \\
\hline 9 & $\begin{array}{l}\text { Other Procedures on } \\
\text { Ear, Nose, Mouth } \\
\text { and Throat }\end{array}$ & 129 & 34.352 .700 & 38.229 .668 & $(3.876 .968)$ & (30.054) \\
\hline 10 & Dental procedures & 3.855 & 1.161 .126 .000 & 1.303.266.577 & (142.140.577) & $(36.872)$ \\
\hline 11 & $\begin{array}{l}\text { Rehabilitation } \\
\text { Procedures }\end{array}$ & 13 & 2.098 .200 & 3.165 .000 & $(1.066 .800)$ & (82.062) \\
\hline 12 & $\begin{array}{l}\text { Other Moderate } \\
\text { Procedures on Ear, } \\
\text { Nose, Mouth and } \\
\text { Throat }\end{array}$ & 2 & 682.000 & 720.442 & $(38.442)$ & $(19.221)$ \\
\hline 13 & $\begin{array}{l}\text { Physical Therapy } \\
\text { Procedure and } \\
\text { Musculoskeletal } \\
\text { Small Procedure }\end{array}$ & 3 & 356.100 & 560.000 & (203.900) & ( 67.967) \\
\hline
\end{tabular}




\begin{tabular}{lccccr}
\hline No. Action Type & $\mathrm{N}$ & $\begin{array}{c}\text { Total Tariff Ina } \\
\text { CBGS }\end{array}$ & $\begin{array}{c}\text { Total hospital } \\
\text { Rate }\end{array}$ & $\begin{array}{c}\text { Total Cost } \\
\text { difference }\end{array}$ & $\begin{array}{c}\text { Cost } \\
\text { Difference } \\
\text { Per Patient }\end{array}$ \\
\hline Total & 7.153 & 1.868 .813 .500 & 1.996 .904 .794 & $(128.091 .294)$ & $(17.907)$ \\
\hline
\end{tabular}

Based on Table 5 most of the actions performed in dental poly are not contributing to profit. The difference between Ina CBGS compared to hospital rates is higher. From the composition of txt bill obtained in specialist dental services in 2019 are as follows on the Table 6;

Table 6 Recapitulation of BPJS Patient Bills taken from BPJS TXT data in 2019

\begin{tabular}{llrr}
\hline No. & \multicolumn{1}{c}{ bill } & $\mathrm{N}$ & $\%$ \\
\hline 1 & Non-Surgical Procedures & 391.069 .500 & $19,45 \%$ \\
2 & Surgical Procedures & 2.968 .460 & $0,15 \%$ \\
3 & Doctor Consultation Services & 1.103 .656 .712 & $54,89 \%$ \\
4 & Nursing Measure & 13.825 .999 & $0,69 \%$ \\
5 & Supporting Actions & 13.825 .999 & $0,69 \%$ \\
6 & radiology & 163.029 .999 & $8,11 \%$ \\
7 & Laboratory & 77.304 .499 & $3,84 \%$ \\
8 & Rehabilitation & 1.350 .000 & $0,07 \%$ \\
9 & Service & 216.555 .990 & $10,77 \%$ \\
10 & Tickets & & $1,32 \%$ \\
11 & Rharmacy & 26.578 .606 & $0,02 \%$ \\
\hline & Rent Tools & 360.000 & $100,00 \%$ \\
\hline
\end{tabular}

Based on Table 6, recapitulation of BPJS bills taken from TCT BPJS Data in 2019 was obtained that there are several types of financing components, namely (1) non-surgical procedures are some poly surgery procedures that only perform non-surgical treatments. This poly dental action contains $19.45 \%$ of the total bill. (2) surgical procedure is a dental in poly procedure that performs surgery with a percentage off $0.15 \%$ of the existing bill, (3) Consulting services are services provided to specialist dentists amounting to $54.89 \%$.

\section{CONCLUSION}

bpjs poly dental specialist examination at Rumah Sakit Islam Surabaya does not contribute maximal benefits to the operation of health services. 


\section{REFERENCES}

Anas, A. S. A., \& Abdullah, A. Z. (2008). Studi mutu pelayanan berdasarkan kepuasan pasien di Klinik Gigi dan Mulut RSUP Dr. Wahidin Sudirohusodo Makassar. Journal of Dentomaxillofacial Science, 7(2), 98. https://doi.org/10.15562/jdmfs.v7i2.199

Andayasari, L. (2014). Analisis Hubungan Fasilitas Pelayanan Kesehatan Gigi Dan Kegiatan Penambalan Dan Pencabutan Gigi Di Puskesmas. Indonesian Journal of Biotechnology Medicine, 3((2)), 85-100.

Dewanto, I. (2014). Penetapan Dokter Gigi Layanan Primer di Indonesia. Majalah Kedokteran Gigi Indonesia, 21(2), 109. https://doi.org/10.22146/majkedgiind.9833

Duarsa, A. M., Sulistiadi, W., \& Sangadji, I. (2019). Strategi Atasi Perbedaan Unit Cost Sectio Caesaria dengan Klaim berdasarkan Tarif INA-CBG's pada Pasien BPJS di Rumah Sakit Khusus Ibu Dan Anak Bunda Liwa. Jurnal Manajemen Dan Administrasi Rumah Sakit Indonesia, 3(2), 142-154.

Kementerian Kesehatan Republik Indonesia. (2009). UNDANG-UNDANG REPUBLIK INDONESIA NOMOR 44 TAHUN 2009 TENTANG RUMAH SAKIT. 27(7).

Konsil Kedokteran Indonesia. (2012). Standar Kompetensi Dokter Indonesia. 1-90.

Lisnawaty. (2008). Rasionalisasi Tarif Berdasarkan Analisis Biaya Satuan, ATP, WTP dan FTP Sebagai Dasar Pemberian Subsidi Silang di Unit Rawat Inap Rumah Sakit Umum Daerah Kabupaten Muna Sulawesi Tenggara. Universitas Hasanuddin, 1-70. http://digilib.unhas.ac.id/uploaded_files/temporary/DigitalCollection/MWFhNjU4 NDM3MzAyNDRjNDUyYzBiYzU4YWExOTE1OGViNWM2YzFkZA==.pdf

Meisida, N., Oni, S., \& Chandra, H. K. (2014). K-Means untuk Klasifikasi Penyakit Karies Gigi. Ilmu Komputer (KLIK ULM) Matematika Fakultas MIPA UNLAM Prodi Komputerisasi Akuntansi POLIBAN, 01(01), 12-22.

Menkes RI. (2005). Kebijakan pelayanan dokter gigi keluarga (pp. 1-25).

Ridha Aulia, Rosihan Adhani, Irham Taufiqurrahman, I. H. (2017). Pengaruh Kualitas Pelayanan Kesehatan Gigi dan Mulut Terhadap Kepuasan Pasien BPJS di Layanan Primer Banjarmasin. DENTINO Jurnal Kedokteran Gigi, II(1), 95-100.

Suharmiati, S., Handayani, L., \& Roosihermiatie, B. (2019). Analisis Biaya Obat Unit Rawat Jalan pada Rumah Sakit Badan Layanan Umum (BLU)/ Badan Layanan Umum Daerah (BLUD) di Indonesia. Jurnal Kefarmasian Indonesia, 126-139. https://doi.org/10.22435/jki.v9i2.1369 